\title{
Holocene environmental changes in Mongolia: A review
}

\author{
Cheng-Bang An ${ }^{\text {a, } *}$, Fa-Hu Chen ${ }^{\text {a }}$, Loukas Barton ${ }^{\mathrm{b}}$ \\ ${ }^{a}$ CAEP, Key Laboratory of Western China's Environmental Systems (Ministry of Education), Lanzhou University, Lanzhou, Gansu 730000, China \\ b Department of Anthropology, University of California, Davis, CA 95616, USA
}

\section{A R T I C L E I N F O}

\section{Article history:}

Received 1 September 2005

Accepted 1 May 2006

Available online 14 June 2008

\section{Keywords:}

Mongolia

Holocene

environmental change

\begin{abstract}
A B S T R A C T
Holocene environmental change in Mongolia is reconstructed on the basis of recently published paleoclimate records, including lake levels, pollen assemblages, and eolian sediment records. These data indicate that the early Holocene of Mongolia is characterized by increasing temperature and humidity. Paleosol development, high lake-stands, and a more southward distribution of forest-steppe environments suggest the early-mid Holocene was humid. The mid-Holocene however is characterized by enhanced aridity, even though the onset and termination of the dry interval differs from place to place. Finally, humidity increased again during the late Holocene, as evaporation decreased in concert with dropping temperatures in Mongolia.
\end{abstract}

(c) 2008 Elsevier B.V. All rights reserved.

\section{Introduction}

Located in the core of the Asian continent, Mongolia is important because variations in the intensity of the Mongolian High Pressure System, which develops over the region and has a strong influence on the winter climate of central-East Asia (Gong et al., 2001), is close in relation to the North Atlantic Oscillations (NAO) and North Pacific Oscillations (NPO) (Kerr, 1999; Gong et al., 2001; Hoerling et al., 2001). Furthermore, the climate and environment of Mongolia are affected by two other global-scale climate systems: westerlies modulated by the North Atlantic Oscillations (NAO) (Visbeck, 2002), and the East Asian summer monsoon which is associated with the El Niño-Southern Oscillations (ENSO) and the Inter-tropical Convergent Zone (ITCZ) (Tudhope et al., 2001). Situated at the junction of these three large-scale climatic systems, Mongolia is important for recording and thus retrieving the Holocene global climatic sequence. However, despite the importance of environmental change in Mongolia for our understanding of large-scale regional Holocene climatic change, the temporal and spatial Holocene palaeoenvironmental sequences within Mongolia itself have not been well established. This paper synthesizes a large body of published material regarding environmental change throughout Mongolia during the Holocene.

\section{Study area and research objectives}

Mongolia occupies a region of extreme continentality (Fig. 1). The climate becomes increasingly moist from south to north due to decreases in temperature and increases in precipitation. The distribu-

\footnotetext{
* Corresponding author. Tel.: +86 931 8914319; fax: +86 9318912330. E-mail address: cban@lzu.edu.cn (C.-B. An).
}

tion of vegetation reflects these climatic influences well. From northern Mongolia to northern China, the vegetation zones are: (1) coniferous forest, (2) forest-steppe; (3) cold steppe; (3) desert steppe; and (4) desert (Fig. 1, Hilbig, 1995). Therefore it is reasonable to study Holocene environmental change in Mongolia along a northsouth transect.

Mongolian Holocene climate change has been studied primarily by researchers from the former Soviet Union. Some research results have been published, mostly in Russian, but little has appeared in international journals. Khotinsky (1989) and Logatchov (1989) summarize the earlier work from Mongolia, concluding that climates during the early Holocene (10-8 kyr BP) and the late Holocene (2.50 kyr BP) were relatively stable. During the mid-Holocene (8-5 kyr $\mathrm{BP}$,) the climate was cool and wet, but between 5 and $2.5 \mathrm{kyr} \mathrm{BP}$, it became and variably warm and dry. Since the 1990s, most Holocene investigations have been based primarily on lacustrine, and eolian deposition, and on tree-ring records, making it possible to reconstruct Holocene climatic change in Mongolia.

The present study is based on the compilation of palaeoclimatic records from the published literature. Because Holocene environmental change in the southern and eastern regions of Mongolia is poorly understood, we use existing palaeoclimatic data from northern China to aid in the interpretation.

For comparison with existing research in Mongolia and adjacent areas, chronological controls in this study are not converted to calendar years.

\section{Paleoenvironmental data}

Here proxy data, such as eolian sediment sequences, lake-level records, lacustrine deposits, and pollen sequences, are used to reconstruct Holocene environmental change. 


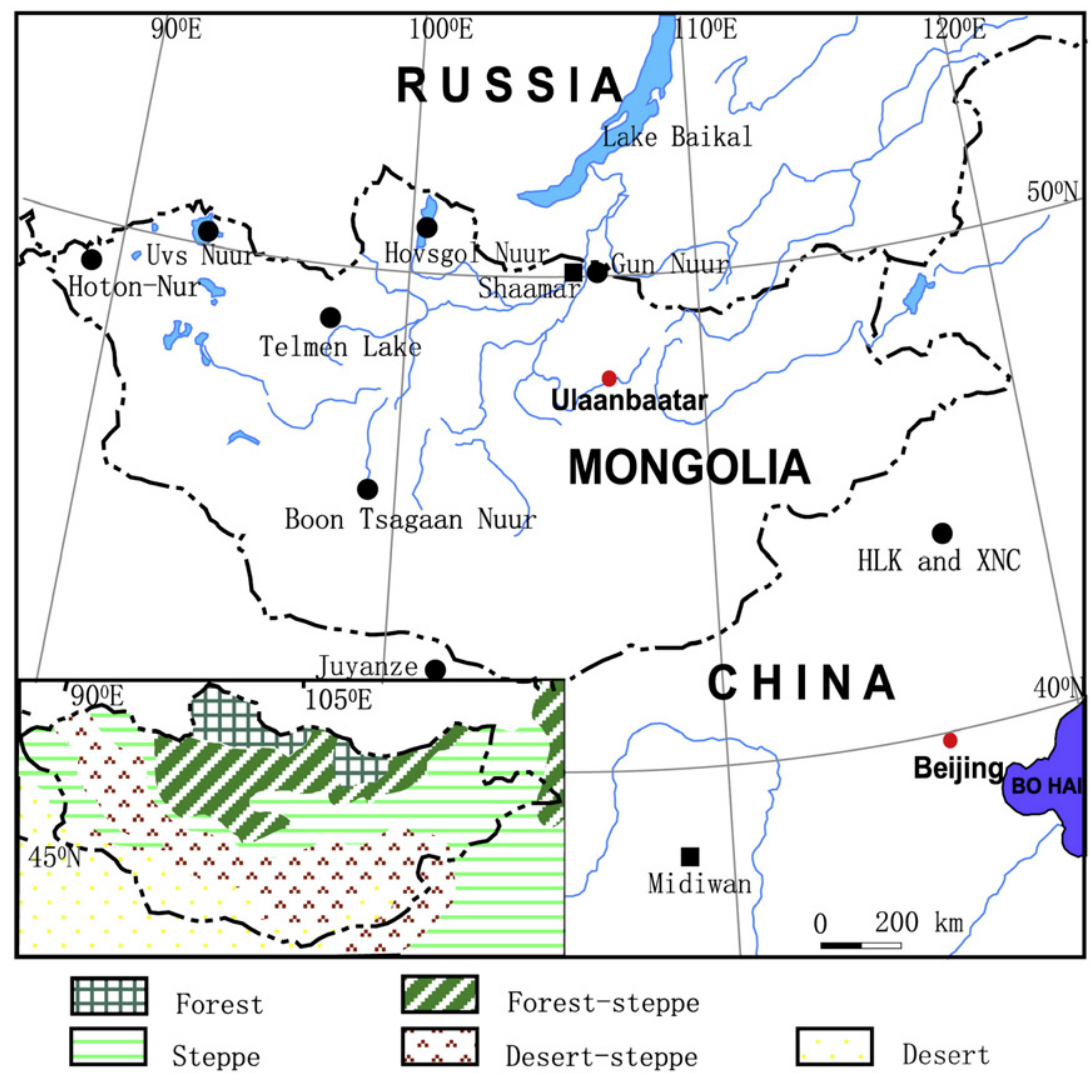

Fig. 1. Map showing the locations of sites mentioned in the text and the distribution of vegetation in Mongolia.

\subsection{Eolian deposits}

The Holocene eolian deposits are wide-spread across Mongolia (northern Mongolia, Feng, 2001; Feng et al., 2005, western Mongolia, Grunert et al., 2000, and central Mongolia, Lehmkuhl and Lang, 2001). However, the thickest and best-preserved eolian sections are found in northern Mongolia (Feng et al., 2005). We reference the Liushuwan (Midiwan) section, a sand/peat sequence from northern China (Zhou et al., 1998; Li et al., 2003) to aid in the interpretation of the southern Mongolian environmental record.

Four sand/loess/soil (or sand/peat) profiles are shown here (Fig. 2): Shaamar sand/soil section $\left(50.2^{\circ} \mathrm{N}, 105.2^{\circ} \mathrm{E}\right)$ in northern Mongolia

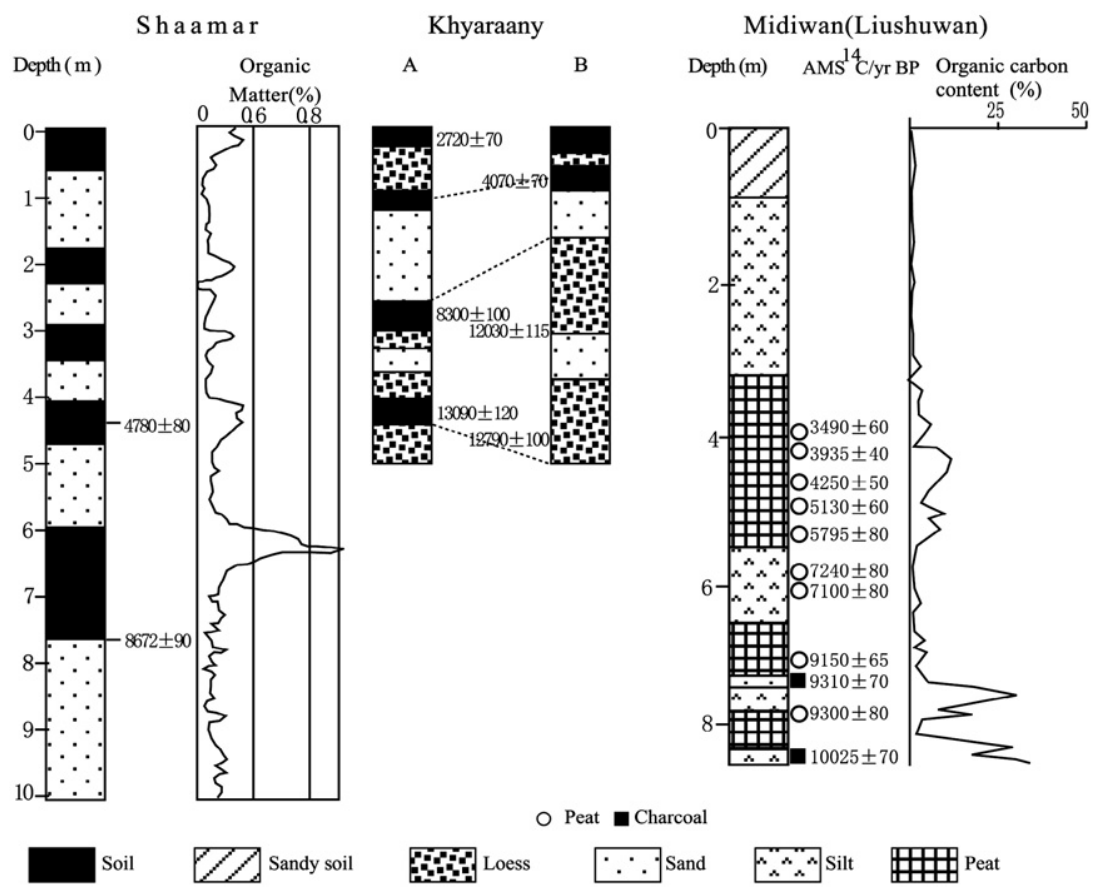

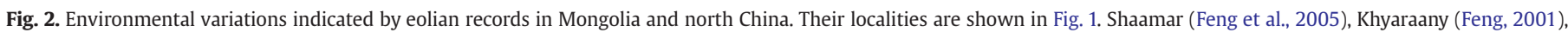
Midiwan (Li et al., 2003). 
(Feng et al., 2005), Khyaraany $\left(50.23^{\circ} \mathrm{N}, 106.73^{\circ} \mathrm{E}\right)$ sand/loess/soil sections (A and B), about $100 \mathrm{~km}$ to east of Shaamar section (Feng, 2001), and the Midiwan sand/peat section from the Ordos Plateau, northern China (Li et al., 2003). According to AMS ${ }^{14} \mathrm{C}$ dates, the Shaamar section contains approximately $10 \mathrm{~m}$ of Holocene subaerial sediments interbedded with five paleosols intervened with sand units. A weak paleosol in the Shaamar section at the depth of 4-5 m was dated to $4780 \pm 80 \mathrm{yr} \mathrm{BP}$ (the only conventional ${ }^{14} \mathrm{C}$ date) and the lower part of a well-developed paleosol was dated at $8672 \pm 90 \mathrm{yr}$ BP. All paleosols are characterized by higher organic matter content. Specifically, the lower paleosol which formed during the early Holocene (i.e., dated at $8672 \mathrm{yr} \mathrm{BP}$ ) is a typical mollisol. In other words, organic matter accumulation suggests that the environmental conditions were different during the early Holocene than during the rest of the Holocene. In the Khyaraany area, sand units alternate with loess units, and visual comparison enables correlation between sections $\mathrm{A}$ and $\mathrm{B}$. Conventional ${ }^{14} \mathrm{C}$ methods were used to date organic matter-enriched layers. The upper correlative stratum of section $B$ has been ${ }^{14} \mathrm{C}$ dated to $4070 \pm 70 \mathrm{yr}$ BP. The lower correlative stratum of section A dates to $13,030 \pm 120 \mathrm{yr} \mathrm{BP}$, while the same stratum in section $B$ dates to $12,790 \pm 100 \mathrm{yr}$ BP. The topsoil (around $0.85 \mathrm{~m}$ depth) of section A was dated at $2720 \pm 70 \mathrm{yr}$ BP. A second organic matterenriched layer (an incipient histosol) at $4.5 \mathrm{~m}$ depth was dated to $8300 \pm 100$ yr BP.

In the Midiwan section a series of climatic fluctuations are reconstructed in the basis of climate-proxy indices and the occurrences of silt, silty peat and aeolian sand (Li et al., 2003). The Holocene Optimum (10,000-7500 yr BP) and another humid interval (4500$3500 \mathrm{yr}$ BP) have also been identified in the region (Li et al., 2003). Here, between 7.5 and $4.5 \mathrm{kyr}$ BP, the organic carbon content was generally low and the climate was dry (Li et al., 2003).

\subsection{Lake-level fluctuations and lacustrine deposits}

Lake-levels are a sensitive index of regional effective moisture, however there have been very few studies of lake-level fluctuations in Mongolia. Using mollusk profiles from lake sediments, Grunert et al. (2000) found that Uvs Nuur, the largest lake in northwestern Mongolia, and adjacent Bayan Nuur reached their highest stands in the upper late glacial and early Holocene, between 11,230 \pm 60 yr BP and 9690 yr BP. During a generally regressive phase, lake-level in the Uvs Nuur was either a lengthy standstill or a slight short-term rise in generally falling water levels. This phase has been dated between $7310 \pm 90 \mathrm{yr}$ BP and $3250 \pm 70$ yr BP. Lastly, lacustrine sedimentation occurred during the late Holocene between $3010 \pm 50 \mathrm{yr}$ BP and $4030 \pm 50 \mathrm{yr}$ BP.

Many Mongolian lake basins were empty during the Pleistocene but began filling with the onset of the Holocene. However, lake evolution in Mongolia during the Holocene is still not thoroughly understood. Three lakes in Mongolia and one in northern China have been studied in detail (Fig. 3). Lake Khubsugul (Hovsgol), which occupies a depression in the Baikal Rift zone of northern Mongolia, has been studied extensively (Altunbaev and Samarina, 1977; Golubev, 1992; Dorofeyuk and Tarasov, 1998; Fedotov et al., 2000, 2001, 2004; Prokopenko et al., 2005). Organic carbon in Holocene deposits of diatomaceous silt decreases abruptly during the mid-Holocene at $c a$. 5.5 kyr BP, suggesting a short-term drought (Fedotov et al., 2004) (Fig. 3). Lake Gun Nuur is south of Lake Khubsugul. The following lithology was observed in the Gun Nuur lake core: a silty mud unit in the upper portion, a unit of laminated carbonate mud in the lower part, and a sand unit in the lowest (Fig. 3). Between approximately 9500 and $6800{ }^{14} \mathrm{C}$ yr BP, low organic matter content suggests low primary productivity (Feng et al., 2005). Then, between approximately 6800 and 2200 yr BP, higher primary productivity is characterized by
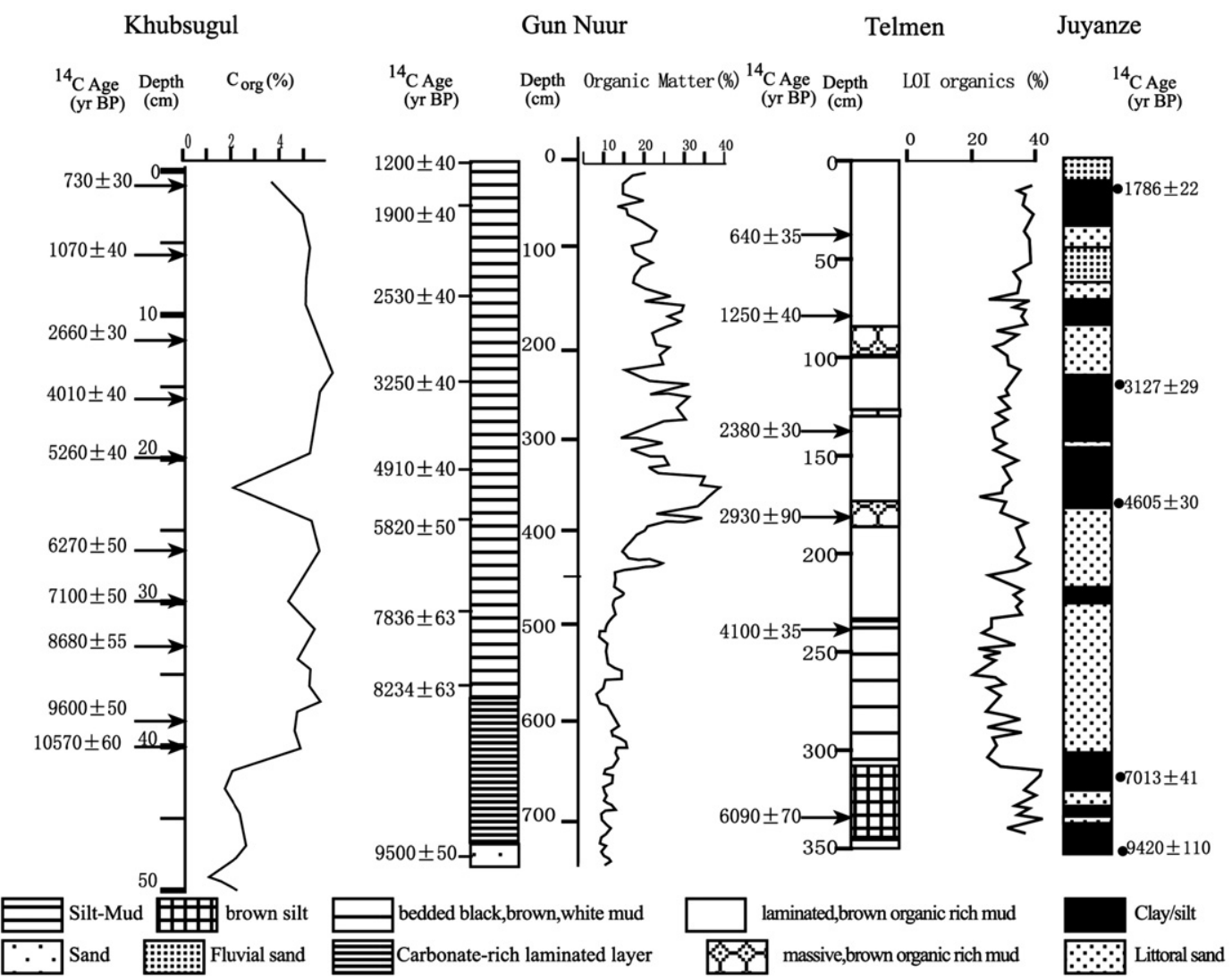

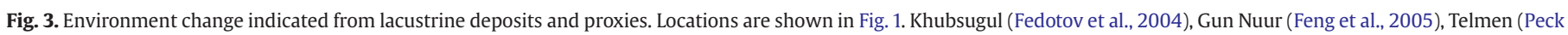
et al., 2002), Juyanze (Chen et al., 2003). 

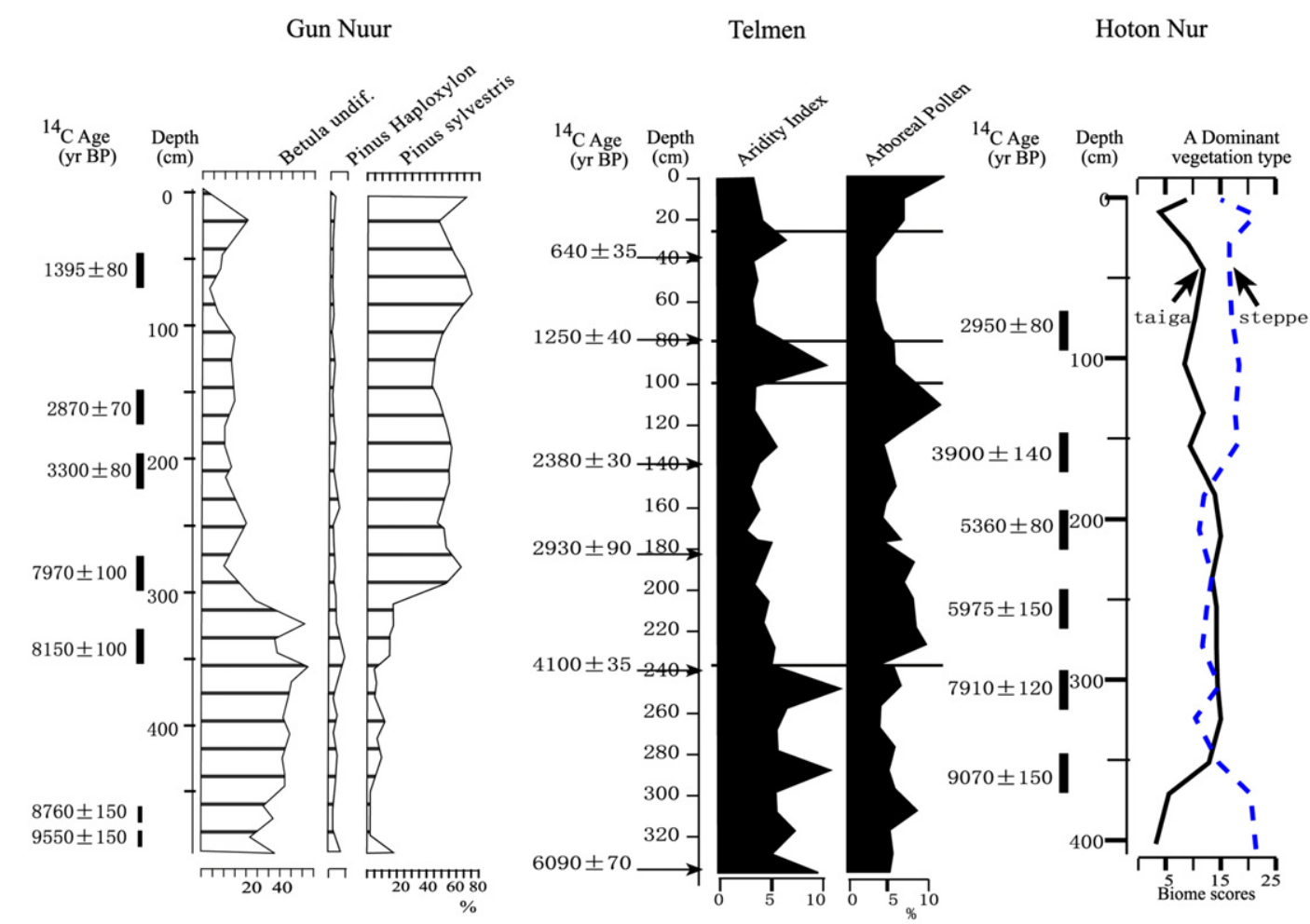

Fig. 4. Environment change as indicated from pollen records. Gun Nuur (Dorofeyuk and Tarasov, 1998), Telmen (Fowell et al., 2003), Hoton-Nur (Tarasov et al., 2000).

increased organic matter content, and higher lake-levels. Following this, the near disappearance of planktonic diatoms and the dominance of benthics between approximately 2200 and $1550{ }^{14} \mathrm{C}$ yr BP indicates that the lake dropped in concert with decreasing primary productivity, which itself is suggested by low organic matter content (Feng et al., 2005). Two cores were collected from Lake Telmen in western Mongolia (Fig. 1) to study Holocene environmental changes (Peck et al., 2002; Fowell et al., 2003). Based on the core stratigraphy (Fig. 3), Peck et al. (2002) proposed that from 7110 to $6260 \mathrm{yr}$ ago Lake Telmen was substantially more shallow than it is at present. Between 6260 and 4390 yr ago the lake rose slightly, and by $4390 \mathrm{yr}$ ago, lake-levels had risen well above the previous low stand. The lake was much higher than it is today between 1260 and $2710 \mathrm{yr}$ BP, after which it dropped again about 1260 years ago. Drilled sediment cores from Juyanze in northern China (Fig. 3), which is close to Mongolia (see Fig. 1), points to fluctuating lake-levels between 9420 and $6500 \mathrm{yr} \mathrm{BP}$, shallow water between 6400 and $4605{ }^{14} \mathrm{C}$ yr BP, and then deep water again until $3120 \mathrm{yr}$ BP, followed by alternations between shallow water, salt deposits, deep water, and dry conditions (Chen et al., 2003).

\subsection{Pollen analyses}

In Mongolia, most biome reconstructions based on palynology have poor chronological controls (e.g. Gunin et al., 1999). Here we review those published palynological records with comparatively reliable chronologies.

At Gun Nuur (Figs. 1 and 4), pollen analysis shows two distinct pollen zones during the Holocene (Dorofeyuk and Tarasov, 1998). From 8000 to $10,000 \mathrm{yr} \mathrm{BP}, 54 \%$ of the total pollen assemblage is arboreal (33\% Betula, 21\% Pinus). After 8000 yr BP, arboreal pollen increases from 63 to $83 \%$, and during this time it is mainly Pinus (Fig. 4). Forest coenosis decreased between 9600 and 8700 yr BP. Pinelarch forests spread across the region during the last $8000 \mathrm{yr}$ BP. Pollen records from Lake Telmen (Fowell et al., 2003) show that between 6100 and $4060 \mathrm{yr}$ BP, the aridity index was high and the climate was more arid than at present. The following period, 4060 to $1650 \mathrm{yr}$ BP is characterized by maximum humidity as indicated by a low aridity index and relatively high proportion of arboreal pollen. A possible arid interval is recorded as a spike in the aridity index between 1650 and $1280 \mathrm{yr}$ BP. Following this brief aridification, a return to relatively humid conditions is signaled by a low aridity index after $1280 \mathrm{yr}$ BP. Pollen and diatom records from Hoton-Nur lake (Figs. 1 and 4) suggests that steppe, which covered the area some time before $9000 \mathrm{yr} \mathrm{BP}$, was replaced by boreal conifer forest-steppe between

\section{Table 1}

\begin{tabular}{|c|c|c|c|}
\hline Period & Climatic variations & Evidence & References \\
\hline \multirow[t]{3}{*}{$\begin{array}{l}\text { Early-mid } \\
\text { Holocene }\end{array}$} & \multirow[t]{3}{*}{$\begin{array}{l}\text { Humid. } \\
\text { Most records show that the } \\
\text { beginning of the Holocene } \\
\text { drier than present but } \\
\text { generally wetter than present } \\
\text { during the early-mid } \\
\text { Holocene }\end{array}$} & $\begin{array}{l}\text { High lake- } \\
\text { levels }\end{array}$ & $\begin{array}{l}\text { Dorofeyuk, 1988; Sevastyanov } \\
\text { et al., 1989; Sevastyanov and } \\
\text { Dorofeyuk, 1992; Dorofeyuk, } \\
\text { 1992; Grunert et al., 2000; } \\
\text { Tarasov et al., 2000; Lehmkuhl } \\
\text { and Lang, 2001; Prokopenko } \\
\text { et al., } 2005\end{array}$ \\
\hline & & Pollen & $\begin{array}{l}\text { Dorofeyuk and Tarasov, 1998; } \\
\text { Gunin et al., 1999; Tarasov } \\
\text { et al., } 2000\end{array}$ \\
\hline & & Palen & 1; Feng et al., 2005 \\
\hline \multirow{5}{*}{$\begin{array}{l}\text { Mid- } \\
\text { Holocene }\end{array}$} & \multirow{5}{*}{$\begin{array}{l}\text { Dry. } \\
\text { The beginning and ending age } \\
\text { of the dry interval differs from } \\
\text { place to place, but it is } \\
\text { worthwhile to point out that } \\
\text { the mid-Holocene drought } \\
\text { increased from north to south }\end{array}$} & Falling & Grunert et al., 2000; Komatsu \\
\hline & & $\begin{array}{l}\text { lake- } \\
\text { levels }\end{array}$ & $\begin{array}{l}\text { et al., 2001; Lehmkuhl and } \\
\text { Lang, 2001; Fedotov et al., } \\
2004\end{array}$ \\
\hline & & Pollen & $\begin{array}{l}\text { Dorofeyuk and Tarasov, 1998; } \\
\text { Fowell et al., } 2003\end{array}$ \\
\hline & & Diatom & $\begin{array}{l}\text { Fedotov et al., 2004; } \\
\text { Prokopenko et al., 2005; Feng } \\
\text { et al., } 2005\end{array}$ \\
\hline & & $\begin{array}{l}\text { Eolian } \\
\text { sedimen }\end{array}$ & Feng, 2001; Feng et al., 2005 \\
\hline \multirow{4}{*}{$\begin{array}{l}\text { Late } \\
\text { Holocene }\end{array}$} & \multirow{4}{*}{$\begin{array}{l}\text { Humid } \\
\text { Humid climate is interpreted } \\
\text { from most Mongolian records, } \\
\text { but the time varies from place } \\
\text { to place }\end{array}$} & High lake- & Tarasov, 1996; Grunert et al., \\
\hline & & levels & $\begin{array}{l}\text { 2000; Komatsu et al., 2001; } \\
\text { Lehmkuhl and Lang, } 2001\end{array}$ \\
\hline & & Pollen & $\begin{array}{l}\text { Peck et al., 2002; } \\
\text { Fowell et al., } 2003\end{array}$ \\
\hline & & Paleosols & Feng, 2001; Feng et al., 2005 \\
\hline
\end{tabular}


9000 and $8500 \mathrm{yr}$ BP. At the same time, planktonic diatoms increased in abundance from 5 to $45 \%$. After 4000 BP, forest cover declined sharply as steppic vegetation was re-established. Changes in the pollen composition suggest the early and middle Holocene were wetter than today (Tarasov et al., 2000).

\section{Discussion}

\subsection{Holocene environmental changes in Mongolia}

According to paleoclimatic data compiled by Harrison et al. (1996) from lakes in northern Mongolia (Dorofeyuk, 1988; Sevastyanov et al., 1989; Dorofeyuk, 1992; Sevastyanov and Dorofeyuk, 1992), high lakelevels at about 7 kyr BP suggest the early Holocene was humid. New evidence from central Mongolia (Lehmkuhl and Lang, 2001) and western Mongolia (Grunert et al., 2000; Tarasov et al., 2000) confirm major lake expansion during the early Holocene (Table 1). This climatic amelioration is also detected in pollen records (Dorofeyuk and Tarasov, 1998; Tarasov et al., 2000) and paleosols (Feng, 2001; Feng et al., 2005). During the humid early-mid Holocene, the limit of the forest-steppe was further south than at present (Gunin et al., 1999; Tarasov et al., 2000), implying a shrinking desert.

A mid-Holocene drought prevailed throughout Mongolia (Table 1), even in the vicinity of Hot-Nur and Uvs Nuur, which turned cool and dry after $5 \mathrm{yr}$ BP. The beginning and end of the dry interval differs from place to place (Fig. 5). It is worthwhile to point out that the intensity of the mid-Holocene drought increased from north to south. For example, though a relatively high abundance of benthic diatoms at Gun Nuur implies it was relatively dry during 6.5-5.4 kyr BP (Feng et al., 2005), the lake-level was at the transgression stage and forest was still the dominant vegetation (Dorofeyuk and Tarasov, 1998). By contrast, pollen records from Lake Telmen (Fowell et al., 2003) suggest, a high aridity index indicating that the prevailing climate was arid and Telmen was at a relative lowstand between 6100 and $4060 \mathrm{yr}$ BP. Meanwhile in central Mongolia, lake levels declined (Komatsu et al., 2001; Lehmkuhl and Lang, 2001), and at Lake Juyanze, which is adjacent to south Mongolia, littoral sand-silt and fluvial sand deposits show that the lake was very shallow and shrinking in comparison to the preceding interval (Chen et al., 2003).

During the late Holocene, a humid climate is interpreted from most Mongolian records (Table 1 ), but the time varies from place to place. At Khyaraany, a soil developed above loess deposits dated to $2720 \pm 70$ (Feng, 2001), and a more humid climate has been documented at Lake Telmen ca. 4060-1650 yr BP (Peck et al., 2002; Fowell et al., 2003). Lacustrine records from central Mongolia provide evidence for a slightly more humid period around 1.5 kyr BP (Komatsu et al., 2001; Lehmkuhl and Lang, 2001). Even in western Mongolia, a slight rise in lake-levels is detected around $3 \mathrm{kyr}$ BP (Grunert et al., 2000). Similar high lake-levels are recorded at Lake Hovsgol between 3650-1800 yr BP during the late Holocene (Tarasov, 1996).

\subsection{Possible mechanism for Mongolian Holocene climate change}

An increase in humidity during the early Holocene is indicated from the results presented above. During this phase, the inclination and solar radiation at $35^{\circ} \mathrm{N}$ (Milankovitch, 1941) was particularly high, which might have intensified the movement of humid air masses from low latitudes towards the desert regions of Africa and Asia (Hövermann et al., 1993). Harrison et al. (1996) compile long-term trends in lake-level changes suggesting that during the Holocene, a gradual strengthening of the summer monsoon leading to high lakelevels during the mid-Holocene. This does not agree with the data presented in this compilation, especially those published recently (Feng, 2001; Komatsu et al., 2001; Lehmkuhl and Lang, 2001; Peck et al., 2002; Fowell et al., 2003; Wang, 2004; Feng et al., 2005).

Though many researchers propose that humidity during the early to mid-Holocene in eastern Asia, including Mongolia, was likely associated with the strengthening and northward displacement of the Pacific monsoon (van Campo and Gasse, 1993; Gasse et al., 1996; Harrison et al., 1996; Tarasov and Harrison, 1998; Gunin et al., 1999),

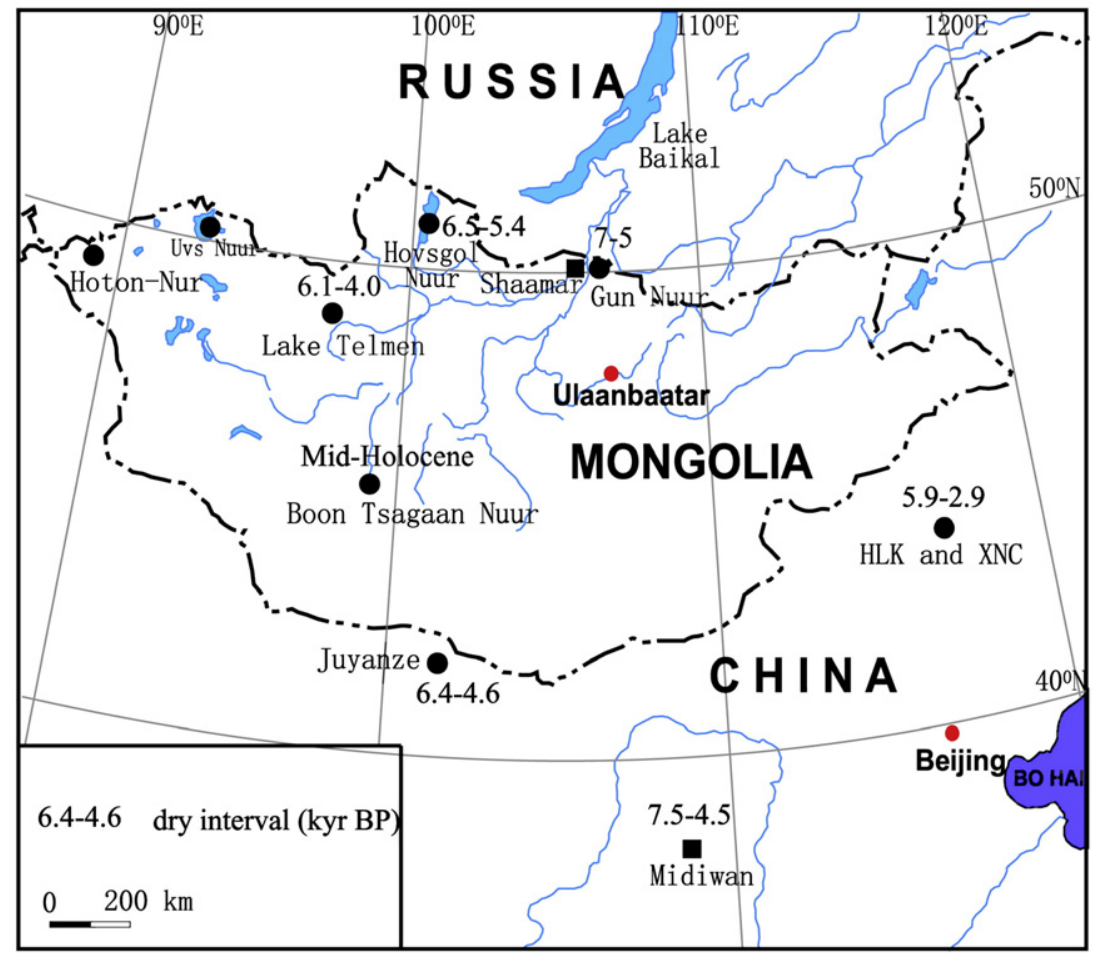

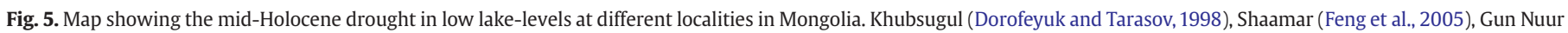
(Feng et al., 2005), Telmen (Peck et al., 2002; Fowell et al., 2003), Juyanze (Chen et al., 2003), HLK and XNC(Liu et al., 2002), Midiwan (Li et al., 2003). 
synthesized geological records from China (Winkler and Wang, 1993) demonstrate that the northern limit of the monsoon was still south of most of Mongolia between 10 and 9 kyr BP. This exception is supported by recently published paleoenvironmental data. First, recently published data point to warming trends during the Holocene in north Eurasia (Dolukhanov, 1997; Velichko et al., 1997; Khotinskyr and Klimanov, 1997; Solovieva and Jones, 2002; Andreev et al., 2002; Feng et al., 2005 and references therein). Here, temperature increased gradually with frequent fluctuations before $8 \mathrm{kyr} \mathrm{BP}$, then changed to a stable, comparatively high-temperature stage between 8 and $5 \mathrm{kyr}$ BP, followed by a period of cooling after 5 yr BP. Second, with climatic amelioration during the early Holocene, permafrost declined and river incision dominated across Mongolia (Owen et al., 1997; Grunert et al., 2000). In Siberia, peatlands developed rapidly and became a global methane source during the early Holocene (Smith et al., 2004). This corresponds with treeline advance between 9000 and 7000 yr BP in eastern Siberia (MacDonald et al., 2000).

A recent review shows that desert aridity increased during the mid-Holocene, while in other parts of arid and semi-arid China dry intervals are more asynchronous than synchronous (An et al., 2006). For example, in non-desert regions of Xinjiang, northwest China, the climate is generally wet during $7000-5000$ yr BP (An et al., 2006). In Mongolia, the early-mid Holocene humidity is followed by a midHolocene drought. Data from northern China, such as those from Juyanze (Chen et al., 2003), Midiwan (Li et al., 2003), and HLK and XNC (Fig. 1; Liu et al., 2002), support this contention. During the relatively stable and warm early-mid Holocene, a strengthening NAO enhanced the westerly, which draws more moisture from the sea to the interior of Eurasia. This is supported by high lake stands in central Asia (e.g. Qin and Yu, 1998; Tarasov and Harrison, 1998). Between 8000 and $3000 \mathrm{yr} \mathrm{BP}$, the northern limits of the summer monsoon moved landward (Shi et al., 1994), and precipitation increased in regions exposed to the expanding Holocene East Asian monsoon in concert with water vapor injections from the westerly. However, in arid and semi-arid regions, the rate of evaporation exceeded the rate of precipitation even under the expanded East Asia monsoon. Thus, effective moisture was reduced in warmer climates. This is the most probable cause of the mid-Holocene drought in Mongolia. Though some studies suggest it was wetter than present from 9 to $4 \mathrm{kyr}$ BP in northern Mongolia, (Tarasov et al., 2000; Feng et al., 2005), a relatively dry phase during the mid-Holocene can be detected in their records. This remarkable mid-Holocene drought is also seen in the Baikal Lake record (Bezrukova et al., 2002). Furthermore, new results based on well-dated pollen records from the Selenga River watershed in Mongolia demonstrate increased continentality after $5 \mathrm{kyr} \mathrm{BP}$, (Bezrukova et al., 2005).

In addition to the weakening of both the summer monsoon (Morrill et al., 2003) and solar radiation (Berger and Loutre, 1991) during the late Holocene, humidity began to increase as a result of decreased evaporation in response to dropping temperatures in Mongolia as recorded in lake-levels and paleosol sequences (see above).

\section{Conclusion}

We suggest that the early Holocene in Mongolia is characterized by increasing temperature and humidity, followed by a humid early-mid Holocene stage, when soils developed, lakes were at high volume, and the limit of the forest-steppe was situated further south than its present position. Enhanced aridity occurred during the mid-Holocene, but the beginning and ending age of the dry interval differs from place to place. In the late Holocene, the humidity increased due to decreased evaporation when temperatures dropped in Mongolia. Better chronological controls and additional studies of sedimentary records are necessary for a more complete understanding of the Holocene environmental changes in Mongolia.

\section{Acknowledgements}

This study was supported by a key project (No. 90502008) and an Innovation Team Project (No. 40721061) granted by the National Natural Science Foundation of China, partly supported by Program for New Century Excellent Talents in University. We would like to thank an anonymous reviewer and Dr. N.W. Rutter for constructive comments that greatly improved this manuscript.

\section{References}

Altunbaev, V.H., Samarina, A.V., 1977. Kharacteristika donnykh otlozheniy Khubsugula (Characteristics of the Khubsugul Lake bottom sediments). Prirodnie Usloviya Resursi Prikhubsuguliya MNRTrudi Sovetsko-Mongolskoi Kompleksnoi Khubsugulskoi Ekspeditsii, vol. 5. Irkutsk University Press, Irkutsk, pp. 80-90 (In Russian)

An, C.-B., Feng, Z.-D., Barton, L., 2006. Dry or humid? Mid-Holocene humidity changes in arid and semi-arid China. Quaternary Science Reviews 25 (3-4), 351-361.

Andreev, A.A., Siegert, C., Klimanov, V.A., Derevyagin, A.Y., Shilova, G.N., Melles, M., 2002. Late Pleistocene and Holocene vegetation and climate on the Taymyr Lowland, Northern Siberia. Quaternary Research 57, 138-150.

Berger, A., Loutre, M.F., 1991. Insolation values for the last 10 million years. Quaternary Science Reviews 10, 297-317.

Bezrukova, E.V., Letunova, P.P., Vershinin, K.E., Krivonogov, S.K., Abzaeva, A.A., Krapivina S.M., Khomutova, M.Yu., 2002. Paleoenvironmental changes in Baikal Basin in the Late Glacial and Holocene. International Symosium-Speciation in Ancient Lakes, SIAL-Irkutsk, 2002, pp. 111-120.

Bezrukova, E.V., Kulagina, N., Letunova, P., Kuzmin, M., Karabanov, E., Abzaeva, A. Vershinin, K., 2005. Late Pleistocene and Holocene vegetation and climate history of the Selenga River watershed, based on well-dated pollen evidences. Third international conference on Environmental change in central Asia. Ulaanbaatar, Mongolia.

Chen, F., Wu, W., Holmes, J.A., Madsen, D.B., Zhu, Y., Jin, M., Oviatt, C.G., 2003. A midHolocene drought interval as evidenced by lake desiccation in the Alashan Plateau, Inner Mongolia, China. Chinese Science Bulletin 48 (14), 1401-1410.

Dolukhanov, P.M., 1997. The Pleistocene-Holocene transition in Northern Eurasia: environmental changes and human adaptations. Quaternary International 41/42, 181-191.

Dorofeyuk, N.I., 1988. Holocene palaeogeography of MPR by diatom record from lake bottom sediments. Nature Conditions Vegetation Cover and Animals of Mongolia, Pushchino, pp. 61-82.

Dorofeyuk, N.I., 1992. Century changes of lakes tanatosenozes and reconstruction of their history (on Buir-Nur Lake example). Ecology and Using of Nature in Mongolia, pp. 151-166 Pushchino, vol. 34, pp. 845-859.

Dorofeyuk, N.I., Tarasov, P.E., 1998. Vegetation and lake levels in northern Mongolia in the last 12,500 years as indicated by data of pollen and diatom analyses. Stratigraphy and Geological Correlation 6, 70-83 (in Russian).

Fedotov, A.P., Bezrukova, E.V., Chebykin, E.P., Velichko, A., Levina, O.V., Mazepova, G.P. Mizandrontsev, I.B., Semenov, A.R., Vorobyova, S.S., Zheleznyakova, T.O., Grachev, M.A., 2000. Potential value of bottom sediments of Lake Khubsugul (Mongolia) for paleoclimate reconstructions. Berliner geowissenschaftliche Abhandlungen. Reihe A, Geologie und Paláontologie 205, 107-112.

Fedotov, A.P., Bezrukova, E.V., Vorob'eva, S.S., 2001. Sediments of Lake Hovsgol as a record of paleoclimates of the Holocene and Late Pleistocene. Geologiya Geofizika 42 (1-2), 384-390.

Fedotov, A.P., Chebykin, E.P., Yu, S.M., Vorobyova, S.S., Yu, O.E., Golobokova, L.P., Pogodaeva, T.V., Zheleznyakova, T.O., Grachev, M.A., Tomurhuu, D., Oyunchimeg, Ts, Narantsetseg, Ts, Tomurtogoo, O., Dolgikh, P.T., Arsenyuk, M.I., De Batist, M., 2004 Changes in the volume and salinity of Lake Khubsugul (Mongolia) in response to global climate changes in the upper Pleistocene and the Holocene. Palaeogeography, Palaeoclimatology, Palaeoecology 209 (1-4), 245-257.

Feng, Z.D., 2001. Gobi dynamics in the Northern Mongolian Plateau during the past 20,000 + yr: preliminary results. Quaternary International 76/77, 77-83.

Feng, Z.D., Wang, W.G., Guo, L.L., Khosbayar, P., Narantsetseg, T., Jull, A.J.T., An, C.B., Li, X.Q. Zhang, H.C., Ma, Y.Z., 2005. Lacustrine and eolian records of Holocene climate changes in the Mongolian Plateau: preliminary results. Quaternary International 136, 25-32.

Fowell, S.J., Hansen, B.C.S., Peck, J.A., Khosbayar, P., Ganbold, E., 2003. Mid to late Holocene climate evolution of the Lake Telmen Basin, North Central Mongolia, based on palynological data. Quaternary Research 59 (3), 353-363.

Gasse, F., Fontes, J.Ch., Van, C.E., Wei, K., 1996. Holocene environmental changes in Bangong Co basin (Western Tibet). Part 4: Discussion and conclusions. Paleogeography, Paleoclimatology, Paleoecology 120, 79-92.

Golubev, V.A., 1992. Dense clays in the uppermost layer of bottom sediments of Lake Khubsugul (Mongolian Peoples' Republic). Doklady Akademii nauk SSSR 324 1091-1095.

Gong, D.Y., Wang, S.W., Zhu, J.H., 2001. East Asian winter monsoon and arctic oscillation. Geophysical Research Letters 28, 2073-2076.

Grunert, J., Lehmkuhl, F., Walther, M., 2000. Paleoclimatic evolution of the Uvs Nuur basin and adjacent areas (Western Mongolia). Quaternary International 65-6, 171-192.

Vegetation dynamics of Mongolia. In: Gunin, P.D., Vostokova, E.A., Dorofeyuk, N.I., Tarsov, P.E., Black, C.C. (Eds.), Geobotany, vol. 26. Kluwer Academic Publishers, Dordrecht. 238 pp. 
Harrison, S.P., Yu, G., Tarasov, P.E., 1996. Late Quaternary lake-level record from Northern Eurasia. Quaternary Research 45, 138-159.

Hilbig, W., 1995. The Vegetation of Mongolia. SPB Academic Publishing, Amsterdam.

Hoerling, M.P., Hurrell, J.W., Xu, T., 2001. Tropical origins for recent North Atlantic climate change. Science 292, 90-92.

Hövermann, J., Lehmkuhl, F., SÜssenberger, H., 1993. Neue Befunde zur Paläoklimatologie Nordafrikas und Zentralasiens. Abhandlungen der Braunschweigischen Wissenschaftlichen Gesellschaft 43,127-150.

Kerr, R.A., 1999. A new force in High-latitude climate. Science 284, 241-242.

Khotinsky, N.A., 1989. Discussion of problems of Holocene correlation and paleoreconstruction. In: Khotinsky, N.A. (Ed.), Paleoclimate of Last Glacial and Holocene Nauka, Moscow, pp. 12-14.

Khotinskyr, N.A., Klimanov, V.A., 1997. Alleröd, younger dryas and early Holocene palaeo-environmental stratigraphy. Quaternary International 41-42, 67-70.

Komatsu, G., Brantingham, P.J., Olsen, J.W., Baker, V.R., 2001. Paleoshoreline geomorphology of Boon Tsagaan Nuur, Tsagaan Nuur and Orog Nuur: the Valley of Lakes, Mongolia. Geomorphology 39 (3-4), 83-98.

Lehmkuhl, F., Lang, A., 2001. Geomorphological investigations and luminescence dating in the southern part of the Khangay and the Valley of the Gobi Lakes (Central Mongolia). Journal of Quaternary Science 16 (1), 69-87.

Li, X.Q., Zhou, W.J., An, Z.S., Dodson, J., 2003. The vegetation and monsoon variations at the desert-loess transition belt at Midiwan in northern China for the last $13 \mathrm{ka}$ Holocene 13 (5), 779-784.

Liu, H.Y., Xu, L.H., Cui, H.T., 2002. Holocene History of Desertification along the Woodland-Steppe Border in Northern China. Quaternary Research 57 (2), 259-270.

Logatchov, N.A., 1989. Late Cenozoic of Mongolia (stratigraphy and paleogeography) The Joint Soviet-Mongolia Scientific Research Transaction, vol. 47. Moscow.

MacDonald, G.M., Velichko, A.A., Kremenetski, C.V., Borisova, O.K., Goleva, A.A., Andreev, A.A., Cwynar, L.C., Riding, R.T., Forman, S.L., Edwards, T.W.D., Aravena, R. Hammarlund, D., Szeicz, J.M., Gattaulin, V.N., 2000. Holocene treeline history and climate change across Northern Eurasia. Quaternary Research 53, 302-311.

Milankovitch, M., 1941. Kanon der Erdbestrahlung und seine Anwendung auf das eiszeitliche Problem. KÖniglich Serbische Akademie, Math.-Nat. Sektion. Belgrad.

Morrill, C., Overpeck, J.T., Cole, J.E., 2003. A synthesis of abrupt changes in the Asian summer monsoon since the last deglaciation. The Holocene 13 (4), 465-476.

Owen, L.A., Windley, B.F., Cunningham, W.D., Badamgarav, J., 1997. Quaternary alluvial fans in the Gobi of southern Mongolia: evidence for neotectonics and climate change. Journal of Quaternary Science 12 (3), 239-252.

Peck, J.A., Khosbayar, P., Fowell, S.J., Pearce, R.B., Ariunbileg, S., Barbara, C.S.H Soninkhishig, N., 2002. Mid to Late Holocene climate change in north central Mongolia as recorded in the sediments of Lake Telmen. Palaeogeography, Palaeoclimatology, Palaeoecology 183 (1-2), 135-153.

Prokopenko, A.A., Kuzmin, M. W. Williams, D.F. Gelety, VF, Kalmychkov, G.V Gvozdkov, A.N., Solotchin, P.A., 2005. Basin-wide sedimentation changes and deglacial lakelevel rise in the Hovsgol basin, NW Mongolia. Quaternary International 136, 59-69.
Qin, B., Yu, G., 1998. Implications of lake level variations at $6 \mathrm{ka}$ and $18 \mathrm{ka}$ in mainland Asia. Global and Planetary Change 18, 59-72.

Sevastyanov, D.V., Dorofeyuk, N.I., Liiva, A.A., 1989. The origin and evolution of the volcanic Terkhiin-Tsagan-Nur Lake in Central Hangai MPR. Izvestiâ Vsesoûznogo Geografičeskogo Obŝestva 121, 137-223.

Sevastyanov, D.V., Dorofeyuk, N.I., 1992. The history of the water ecosystem of Mongolia. Izvestiâ Vsesoûznogo Geografičeskogo Obŝestva 124, 123-138.

Shi, YF, Kong ZC. Wang S.M. Tang LY, Wang F. B. Yao, T.D Zhao, X.Z., Zhang, P.Z., Shi, S.H., 1994. The climate fluctuation and important events of Holocene Megathermal in China. Science in China (Series B) 37, 353-365.

Smith, L.C., Borisova, O.K., Frey, K.E., Kremenetski, K.V., Sheng, Y., MacDonald, G.M., Velichko, A.A., Beilman, D.W., 2004. Siberian peatlands a Net carbon sink and global methane source since the Early Holocene. Science 303, 353-356.

Solovieva, N., Jones, V.J., 2002. A multiproxy record of Holocene environmental changes in the central Kola Peninsula, northwest Russia. Journal of Quaternary Science 17 (4), 303-318.

Tarasov, P.E., 1996. Lake Status Records from the Former Soviet Union and Mongolia: Documentation of the Second Verson of the Database. World Data Center-A for Paleoclimatology, Boulder, Colorado.

Tarasov, P.E., Harrison, S.P., 1998. Lake status records from the Former Soviet Union and Mongolia: a continental-scale synthesis. Paläoklimaforschung 25, 115-130.

Tarasov, P.E., Dorofeyuk, N., Meteltseva, E., 2000. Holocene vegetation and climatic changes in Hoton-Nur basin, northwest Mongolia. Boreas 29, 118-126.

Tudhope, A.W., Chilcott, C.P., McCulloch, M.T., Cook, E.R., Chappell, J., Ellam, R.M., Lea, D.W., Lough, J.M., Shimmield, G.B., 2001. Variability in the El Niño-Southern oscillation through a glacial-interglacial cycle. Science 291,1511-1517.

van Campo, E., Gasse, F., 1993. Pollen- and diatom-inferred climatic and hydrological changes in Sumxi Co basin, Western Tibet since 13000 yr BP. Quaternary Research 39, 300-313.

Velichko, A.A., Andreev, A.A., Klimanov, V.A., 1997. Climate and vegetation dynamics in the tundra and forest zone during the late glacial and Holocene. Quaternary International 41/42, 71-96.

Visbeck, M., 2002. The ocean's role in Atlantic climate variability. Science 297, 2223-2224.

Wang, W.G., 2004. The Holocene climate and environment changes in the northern Mongolian Plateau. PH.D. Dissertation, Lanzhou University, China.

Winkler, M.G., Wang, P.K., 1993. The late-Quaternary vegetation and climate of China. In: Wright, H.E., Kutzbach, J.E., WebbIII III, T., Ruddiman, W.F., Street-Perrott, F.A., Bartlein, P.J. (Eds.), Global Climates Since the Last Glacial Maximum. University of Minnesota Press, Minneapolis, pp. 265-293.

Zhou, W.J., An, Z.S., Jull, A., Donahue, D.J., Head, M.J., 1998. Reappraisal of Chinese Loess Plateau stratigraphical sequences over the last 30000 years: precurses of an important Holocene monsoon climatic event. Radiocarbon 40 (2), 905-913. 